\title{
MODALITY AND INTENTIONALITY OF MEDIA DISCOURSE
}

\author{
Tatiana Karpilovitch ${ }^{1}$
}

\begin{abstract}
The paper investigates the role of lexical and grammatical means of modality in realising intentionality of media discourse. The discourse category of intentionality is understood as the main communicative purpose of a discourse genre which determines its overall structure, the author's communicative strategies and the linguistic means for their representation. The research is based on material of problem feature articles excerpted from the American press. The paper focuses on the pragmatic analysis of language units expressing propositional modality (possibility, necessity) and illocutionary modality (imperatives and interrogatives) used in different structural parts of a problem feature article. The results demonstrate a different potential of modal utterances with these meanings to express the author's global intention - suggesting ways of solving the problem raised in the article. A special procedure has been worked out to prove the connection between the modal utterance and the intentionality of the media discourse genre under study.
\end{abstract}

Keywords: modality, intentionality, media discourse, discourse genre, problem feature articles.

\section{Introduction}

Modern discourse studies focus on the pragmatic, social and cultural conditions of using language units in the processes of understanding and constructing discourses of different types and genres. In this respect, important are modus categories of discourse which disclose the attitude of the author and other communicants to the events, actions and opinions reflected in the discourse. Modality as a modus category is usually treated on an utterance level but it can be also regarded on a discourse level if we are to understand it as the main idea/ message of the discourse as a whole. This kind of modality is formed with the help of different language units, including lexical and grammatical means of modality, evaluative lexis, stylistic devices (metaphors, epithets, etc.). The message of the discourse is closely connected with its main topic and the author's intentions. To identify the author's message in discourse, it is necessary to reveal its intentionality and determine the means of its verbalisation in discourse. There are different classifications of modus categories but most linguists point out intentionality, subjectivity, evaluation, emotivity, and modality. In this paper, I will focus on intentionality and modality because these categories are

1 Professor, PhD at Minsk State Linguistic University, Head of the Department of Theory and Practice of the English language, Minsk, Republic of Belarus, e-mail: tkarp@tut.by 
closely connected: intentionality is the starting point of discourse generation, it is also a regulator of discourse development; modality realises the intentions of the author and other communicants in concrete utterances and on a discourse level.

\section{Previous research in the field}

In analysing the discourse categories of intentionality and modality I proceed from the view that intentionality is closely connected with the notion of goal setting, which is considered a preverbal phenomenon determining the global task of communication, which can be an informative message, description of events, persuasion to perform an action, etc. (Oleshkov, 2005). Important for the research is the assumption that on the basis of communicative intentions the author chooses strategies of verbal behaviour and generates discourse of this or that genre. It is necessary to define the notion of discourse genre because typical communicative purposes are usually associated with certain discourse genres. M. Bakhtin claimed that communication is impossible outside genres; he defined genres as "relatively stable thematic, compositional and stylistic types of utterances" (Bakhtin, 1979, pp. 241-242). Though some genres are rigidly standardised, others can be flexible in their formal and stylistic organisation.

At present, genres tend to be perceived by scholars not only as fixed formulas "but as sets of socially situated and variable conventions and expectations regarding textual forms" (Solin, 2011, p. 119). For the analysis of intentionality and its links with modality it is important to consider the approach to genre by John Swales who defines genres through their communicative purposes:

A genre comprises a class of communicative events, the members of which share some set of communicative purposes. These purposes are recognized by the expert members of the parent discourse community and thereby constitute the rationale for the genre. This rationale shapes the schematic structure of the discourse and influences and constrains choice of content and style. (Swales, 1990, p. 58)

The rationale of the genre also influences the choice of topic, content, structure and vocabulary. In this paper, I will investigate how the communicative purposes of the author of a discourse genre influences the choice of modal language units.

When treated on a sentence / utterance level modality is defined and classified in a different way by scholars. For instance, one of the definitions of modality runs as follows: it is the "manner in which the meaning of a clause is qualified so as to reflect the speaker's judgment of the likelihood of the proposition it expresses being true" (Quirk, Greenbaum, Leech, \& Svartvik, 1985, p. 219). Other linguists believe that modality expressed in an utterance is a category 
which deals with "the status of the proposition" (Lyons, 1977; Palmer, 2001). F. Palmer defines modality as semantic information associated with the speaker's attitude or opinion about what is said. In this paper, I will hold F. Palmer's point of view and consider that modality shows whether a certain proposition is necessary, obligatory, possible, probable, volitional, etc. Hence the following types of modality are distinguished on the propositional level: necessity, possibility, certainty, supposition, volition, ability, etc. These meanings in the English language are expressed by modal verbs, modal adjectives, modal adverbs, modal nouns, intonation, etc.

Apart from the so-called propositional types of modality, some linguists (Paducheva, 1996) distinguish illocutionary modality associated with communicative types of utterances (declarative, imperative and interrogative), which are differentiated according to the communicative purpose of the utterance. Being different structural types of modality, the propositional and illocutionary modality are connected in their main meaning of conveying the attitude of the speaker to the information contained in the utterance. The realisation of these two types of modality will be analysed in this paper from the point of view of their relations to the global communicative purpose (intentionality) of the media discourse under study.

\section{Research questions}

For close consideration of modal meanings, which contribute to the realisation of intentionality of media discourse, I chose feature articles devoted to the discussion of topical problems in different spheres of life: politics, economy, culture, sports, lifestyle, etc. For the relevant discourse, I use the term problem media discourse; for the genre in question - a problem feature article. The articles chosen for the analysis were taken from the American newspapers: The New York Times, The Wall Street Journal, The Seattle Times, and USA Today. All of them were published in the time period 2009-2015. Fifty articles were selected for the analysis.

The paper aims to answer the following questions:

1) What types of modals are used in the initial parts (title, subtitle, lead) of a problem feature article to signal its intentionality?

2) How do different types of modality used in the main body of a problem feature article contribute to the realisation of its main communicative purpose?

3) What are the proofs that a modal utterance is connected with the main intention of the author of a problem feature article?

4) What is the specificity of the relations between intentionality and modality as they are expressed in the concluding part of a problem feature article? 


\section{Methods}

While analysing the intentional structure of problem feature articles I follow T.A. van Dijk's point of view that "intentions can be studied in the same way as meanings: (a) introspection, (b) verbal accounts, (c) inferences from discourse" (Duranti, 2015, p. 155). Special attention is given to the analysis of contextual factors when revealing the links between modal utterances and the global communicative purpose of the discourse. Quantitative analysis is employed in identifying the frequency of modals of different types contributing to the realisation of intentionality of the discourse genre under study.

\section{Data analysis}

I will now discuss the relations between the discourse categories of intentionality and modality, i.e. under what conditions modal utterances can indicate the global intentions of the author of media discourse.

As it has been found in previous research, the main communicative goal (intention) of the author of a problem feature article is to define ways of solving the problem on the basis of considering the views of all the discourse participants, including representatives of the government, social, and private organisations, experts, individuals (Karpilovitch, 2017).

The paper focuses on some types of modal meanings and means of their verbalisation which contribute to the realisation of intentionality of problem feature articles: the meanings of possibility, necessity and illocutionary modality in the form of imperatives and interrogatives because declarative utterances without modals are unmarked for modality. The analysis of the chosen articles showed that the most frequent modals of possibility include the modal verbs can and may; modals of necessity - the modal verbs must, should and quasi-modals need to, have to. It was found that such means become especially prominent when used in the initial parts of the discourse. Though ways of solving the problem are usually considered after pointing out the essence and the causes of the problem, there is quite a number of articles (32\%) in the analysed corpus where the author's leading intention is realised in a title (see ex. 1), a subtitle (see ex. 2), or a lead (see ex. 3) with the help of modals showing the attitude of the author or other participants to the action / state as necessary, possible, or advisory.

(1) Despite Isaac, GOP Vows Show Must Go on. (USA Today. August 24, 2014)

(2) The State is No. 2 in the country in terms of wind power-and its policies may be a model for other states, as well as for the feds. ("The Answer Is Blowing in ... Iowa." The Wall Street Journal. October 19, 2009) 
(3) The Federal Reserve should wait until the first half of 2016 before raising interest rates because inflation remains too low ... ("IMF to Fed: Hold off on Hike." USA Today. June 5, 2015)

Utterances expressing illocutionary modality in the form of imperatives in most cases express advice to the communicants on how to behave in the problem situation depicted in the article (see ex. 4,5 ):

(4) If you Can Pull it off, Buy a House. (USA Today. August 10, 2012)

(5) Build it with tax incentives and Hollywood will come to Iowa. (The Wall Street Journal. October 19, 2009)

Negative structures with the modal units under consideration are used in the titles for recommending the addressee not to undertake this or that action (see ex. 6,7) and in such cases are intertwined with illocutionary modality of imperatives:

(6) You Don't Have to Conform to Do Well at Work. (The Seattle Times. July 20, 2014)

(7) Taking Social Security Right away May not Be Best Move. (The Seattle Times. July 20, 2014)

It should be noted that titles and subtitles containing modal units do not always concern ways of solving the problem. They can be used to verbalise other constituents of the semantic structure of a problem feature article, e.g., the causes (see ex. 8) or consequences of the problem (see ex. 9), which are made obvious by the predicate-argument structure of the utterances:

(8) Experts: Social Media Can Feed Child-Harming Disorder. (The Seattle Times. July 20, 2014)

(9) It's official: Recession ended June 2009. But impact may depend on where you live. (USA Today. September 21, 2010)

In the main body of the article, as the discourse unfolds, different ways of solving the discussed problem are suggested by the author of the article and other participants of communication. The language indicators of the latter are, in the first place, utterances with direct or indirect speech and indicators of the social status of the person whose opinion is given, for instance: chief science adviser, council member, executive director, executive vice president of commercial and public affairs, general counsel for the National Retail Federation, a spokeswoman for the university, a port manager, the industry group's president, senior vice president of corporate development, etc. These indicators are usually combined with verbs denoting a speech activity (add, comment, confirm, note, say, tell, write, etc.) or with an introductory prepositional phrase (according to, in the opinion of). Speaking of modal units, the statements can contain modals 
of possibility (see ex. 10), which is a more frequent case (57\% of all opinionmaking statements), or modals of necessity (see ex. 11):

(10) For individuals, Hewlett says one of the key steps you can take on the tight-rope between conformity and authenticity is to decide what is negotiable and what is not. ("You Don't Have to Conform to Do Well at Work." The Seattle Times. July 20, 2014)

(11) "I think a governor has to understand that employers can outsource labor to other locations that are more competitive, just like U.S. companies go abroad," Steve Gordon, president of Gordon Trucking, told me. ("How Next Governor Can Keep State Competitive." The Seattle Times. October 14, 2012)

It is necessary to prove that an utterance, containing modal verbs, is connected with the main intention of the author - finding ways of solving the problem discussed in the article. For this purpose, I suggest a two-step procedure: a) identify the propositional structure of the utterance/ clause containing a modal; b) establish a correlation between the utterance proposition and the intentionality of the article. In example (10) the modal predicate can take is connected with the subject you which shows that reference is made to the reader of the article. The attributive clause (you can take ...) modifies the noun step, which is a proof that the advice of the participant (Hewlett) concerns actions which, in her opinion, the addressee can undertake. The fact that this advice is connected with the author's main intention can be confirmed by establishing links between the utterance analysed and the title of the article, which is also a piece of advice to the addressee ("You Don't Have to Conform to Do Well at Work"). This analysis shows that there are recurrent words in the utterance and the title: the personal pronoun you and words with the same root: conformity conform. So, we have proved that the utterance with the modal verb can (see ex. 10) contributes to the realisation of the main communicative purpose of the feature article expressed briefly by its title.

In cases when the title (subtitle or lead) does not clearly express the main communicative goal of the article it is necessary to analyse the context in order to prove the existence of a correlation between the modal utterance and intentionality of the discourse as a whole. This context can be broad or rather narrow like in the following example (see ex. 12) where the phrase "to reduce problems associated with undocumented residents" shows that the speaker's opinion concerns ways of solving the problems discussed in the article:

(12) But Mehlman, of the anti-illegal immigration activist group, said if Los Angeles wants to reduce problems associated with undocumented residents it should make life harder, not easier, for them, as states such as Arizona 
have done. ("L.A. Mayor Backs City Photo-ID Card." The Seattle Times. October 14, 2012)

Suggestions of the discourse participants on how to solve the problem can be addressed to the readers (see ex. 10), i.e. to the mass addressee but more often to the organisations or people who are responsible for a concrete sector of political, social or economic life (see ex. 13, 14):

(13) The companies have to figure out how the different pieces of technology work together, from the high-tech plastic bags to the bio-engineered algae, Dow executives say. ("Chemical Solution." The Wall Street Journal, October 19, 2009)

(14) The new governor must work to keep our economic clusters competitive, but none is more important or problematic than aerospace and Boeing. ("How Next Governor Can Keep State Competitive." The Seattle Times. October 14, 2012)

The opinion of the author of the article regarding ways to solve the problem is not often marked explicitly by personal (I) or possessive pronouns (my, mine) due to the objectivity principle of the press, though the use of modals clearly shows the attitude of the author of the article (see ex. 15). The inclusive plural pronoun we can be used to implement the strategy of solidarity with the addressee (see ex. 16):

(15) Schools and youth groups should work to make young adults more aware of how to ace a personality test. But employers, particularly those hiring teens, should consider how much they rely on personality tests ... ("Workplace Personality Tests Backfire on Youth." (USA Today, June 5, 2015)

(16) So, we should strive for authenticity, but do so in a way that blends who we are with what is required to succeed at work. ("You Don't Have to Conform to Do Well at Work." The Seattle Times. July 20, 2014)

The author of the article often reasons on implementing different approaches to tackling the problem discussed in the article before he/she chooses one which is most appropriate or effective. For example, in the article written by the executive director of the Washington Higher Education Coordinating Board concerning possibilities for young citizens to continue their education after school the author at first considers the possibility for young people to focus on life experience as there is an example of Bill Gates and a handful of other individuals who succeeded without earning their degrees. But then he criticizes this approach giving arguments which are in accordance with the idea expressed in the title (see ex. 17): 
(17) Life experience can teach many valuable lessons, but it is most often a poor substitute for the knowledge, skills, discipline and employment opportunities gained through successful post-secondary education program. ("No Substitute for Higher Education." The Seattle Times. September 21, 2010)

As for the means of illocutionary modality, rhetorical questions represent an implicit means of expressing opinions on how to deal with the problem discussed. In example 18, the rhetorical question refers to the preceding context, asserting the idea of continuing the implementation of self-regulation, which is working very well:

(18) "We have self-regulation. It's working very well," he says. "Why don't we give that a chance to succeed?" (Do not Track? Advertisers Say 'Don't Tread on Us.' The New York Times. October 14, 2012)

But the majority of questions used in the analysed corpus of articles are intended for attracting the reader's attention to the causes of the problem discussed (ex. 19) or marking a point in the author's reasoning to find a way in order to solve the problem (ex. 20). In such cases questions are always supplied with answers given by the author:

(19) Why did the administration get it wrong? It wasn't exaggerated faith in the power of its stimulus plan; the report predicted a fairly rapid recovery even without stimulus. ("GOP is Dead Wrong on the Economy." The Seattle Times. October 14, 2012)

(20) If spending money on health care does not make U.S. healthier, what does? There is one strong predictor of national health: income inequality. ("If There Were a Health Olympics, the U.S. Wouldn't Even Medal." The Seattle Times. August 8, 2012)

Imperatives are typical of the articles which contain recommendations on how to succeed in a certain area (see ex. 21):

(21) Keep Boeing happy. < ..> Payattention to business costs and headaches. ("How Next Governor Can Keep State Competitive." The Seattle Times. October 14, 2012)

A variety of possibilities that a decision of the problem opens up may be emphasized by repetition of the modal verb can, which is evident in the following example (see ex. 22):

(22) Each time the investors make a trade, KaChing will automatically make the same trades for the customers. Customers can log on whenever they want to check their portfolio's performance. They can send the investor private messages and receive alerts if the investor does something unusual. With the click of a mouse, customers can stop mirroring an investor. ("Site Lets 
Investors See and Copy Experts' Trades." The New York Times. October 19, 2009)

The concluding paragraph of a problem feature article often contains an explicit expression of a way / ways of solving the problem discussed ( $42 \%$ of all the analysed articles). Most often it is the opinion of a discourse participant (not the author of the article), which is expressed by direct or indirect speech. It can be regarded as a compressed expression of the leading intention of the genre. Of all the modal verbs studied in this paper the most frequent are should and need to (see ex. 23, 24), which can be attributed to the deontic modality that these modals express, i.e. "prioritizing modality" (Portner, 2009, p. 135):

(23) The National Reverse Mortgage Lenders Association shares consumers' concerns that all advertising should be accurate, said Peter Bell, the industry group's president ("Reverse Mortgage Ads Shady, Feds Say." USA Today. June 5, 2015).

(24) Before they embark on life experiences, many more of our younger citizens need to engage in rigorous study guided by experienced faculty in highly supportive learning environments. We need to raise our expectations for ourselves and our society, not lower them ("No Substitute for Higher Education." The Seattle Times. September 21, 2010).

The concluding paragraph of a problem feature article can comprise an imperative sentence, which is a means of expressing illocutionary modality. For example, the article concerning a person's behavior at work ends with the advice of an expert (see ex. 25):

(25) 'Don't compromise your authenticity to such an extent that it puts your sole in play. It will make you miserable and will also backfire, because in the end gravitas rests centrally on your true identity" ("You Don't Have to Conform to Do Well at Work." The Seattle Times. July 20, 2014).

\section{Key findings}

The discourse analysis of the categories of intentionality and modality has revealed their close connections in problem feature articles excerpted from American newspapers. Intentionality, which is understood as the main communicative goal of a discourse genre, in problem feature articles is defining ways of solving the problem. It has been found that this intention can be verbalised in the initial positions of a problem feature article: a headline, a subtitle or a lead with the markers of propositional modality (modal verbs of necessity and possibility) and imperatives as representatives of illocutionary modality. The links between intentionality and modality are further actualised in the process of discourse development and can be proved by determining a correlation of the 
modal utterance and the main communicative purpose of the article on the basis of contextual analysis. To identify the existence of such a correlation, a special procedure has been worked out, which consists of two steps: a) determining the propositional structure of the modal utterance, b) establishing links between the proposition of the modal utterance and intentionality of the article as a whole. The second step should be accomplished by analysing contextual factors with priorities being given to the initial and concluding parts of the article, which often contain a compressed expression of its intentionality.

\section{Conclusion and implications}

The findings and generalisations from the present paper may contribute to:

- a better understanding of the intentional structure of other media genres;

- a more profound comprehension of the role of modal utterances in media discourse and their contribution to the realisation of its intentionality;

- an investigation of the role of other linguistic resources in realising the intentionality of media discourse;

- the use of the findings in teaching English as a foreign language, in particular, in the disciplines of discourse interpretation and stylistic analysis;

- developing computer algorithms of discourse summarisation and opinion mining.

\section{References:}

Bakhtin, M. (1979). Estetika slovesnogo tvorchestva [Aesthetics of verbal art]. Moscow: Iskusstvo.

Duranti, A. (2015). The anthropology of intentions: Language in a world of others. Cambridge: Cambridge University Press.

Karpilovitch, T. (2017). Semantic and pragmatic structure of problem feature articles in American and Belarusian media discourse. Discourse Studies - Ways and Crossroads (pp. 97-109). Frankfurt am Main: Peter Lang GmbH.

Lyons, J. (1977). Semantics. Vol. 2. Cambridge: Cambridge University Press.

Oleshkov, M. (2005). Intetsional'nost' v kommunikativnom protsesse (na materiale didakticheskogo diskursa) [Intentionality in the communicative process (on the material of didactive discourse)]. Politicheskaja lingvistika [Political Linguistics], 16, 204-208.

Paducheva, E. V. (1996). Semanticheskie issledovanija. Semantika vremeni $i$ vida v russkom jazyke. Semantika narrativa [Semantic research. Semantics of tense and aspect. Semantics of the narrative]. Moscow: Jazyki slavjanskoi kul'tury.

Palmer, F. R. (2001). Mood and modality. Cambridge: Cambridge University Press.

Portner, P. (2009). Modality. Oxford surveys in Semantics and Pragmatics. Oxford: Oxford University Press. 
Quirk, R., Greenbaum, S., Leech, G., \& Svartvik, J. (1985). A Comprehensive grammar of the English language. New York: Longman.

Solin, A. (2011). Genre. In O. Ostman, \& J. Verschueren (eds.), Discursive pragmatics. (pp. 119-134). Hamburg University of Antwerpen, University of Helsinki: John Benjamins Publishing Company.

Swales, J. (1990). Genre Analysis: English in academic and research settings. Cambridge: Cambridge University Press. 